\title{
REPRESENTASI SIKAP TOKOH UTAMA DALAM MITOS NOVEL SIMPLE MIRACLES DOA DAN ARWAH KARYA AYU UTAMI TERHADAP MASYARAKAT
}

\author{
IRFAN EFENDI \\ Universitas Muhammadiyah Malang \\ Pendievan5531@gmail.com
}

\begin{abstract}
Abstrak
Karya sastra memiliki banyak hasil karya yang memiliki identitas yang berbeda-beda, novel merupakan salah satu karya sastra yang banyak dijadikan pengarang atau sastrawan untuk mengejawantahkan sebuah makna, budaya, atau cerita kehidupan dengan mengemasnya dalam sebuah bahasa yang berbentuk cerita. Setiap novel yang ditulis pengarang pasti memiliki pesan-pesan tersendiri yang mampu dimaknai pembaca. Di dalam novel simple miracles doa dan arwah karya Ayu utami, pembawaan aspeknya ke ranah social dan budaya. Dengan menggunakan tokoh "aku" Ayu utami membahas beberapa kebudayaan yang mengacu kepada ritual-ritual di dalam lingkungan masyarakat. Tokoh "aku" yang di tulis Ayu utami memeliki sikap yang unik dalam memaknai sebuah ritual-ritual dalam kebudayaannya. Tujuan daripada penelitian ini ialah untuk menjelaskan dan menggungkapkan makna yang di maksud dalam novel juga sebagai bentuk penggungkapan karya sastra terhadap realita kehidupan di dalam masyarakat yang mana pengarang memilih topik untuk di jadikan konflik dalam karyanya, sekaligus karya sastra mempunyai peran penting untuk menyampaikan ke adaan sosial masyarakat. Teori dan metode yang di gunakan adalah hermeneutika. Metode ini di gunakan untuk penelitian teks-teks yang sifatnya otoritatif. Hasil dari pembahasan ini adalah atas terdapat nilai moral dan pembelajaran bahwasannya mempercayai bukan sekedar percaya akan tetapi harus ada keyakinan dalam diri manusia sehingga akan mendapatkan ke bahagiaan setelah manusia mempunyai akhlak yang baik.
\end{abstract}

Kata Kunci:tokoh utama, novel, lokalitas karya sastra

\section{PENDAHULUAN}

Bentuk karya sastra sebuah novel merupakan karya tulis yang mempunyai banyak konflik yang di tulis oleh pengarang untuk memunculkan estetika dalam sebuah karyanya. Dengan begitu pengarang mempunyai keleluasan untuk menjawantahkan ide dan gagasannya melaluai karya tulis dengan membawa konflik-konflik dari segala aspek (sosial, budaya, politik, ekonomi). Di dalam novel simple miracles doa dan arwah karya Ayu utami, pembawaan aspeknya ke ranah sosial dan budaya. Dengan menggunakan tokoh "aku" Ayu utami membahas beberapa kebudayaan yang mengacu kepada ritual-ritual di dalam lingkungan masyarakat. Tokoh "aku" yang di tulis 
Ayu utami memeliki sikap yang unik dalam memaknai sebuah ritual-ritual dalam kebudayaannya. Dalam konteks yang sama ritual berkaitan erat dengan mitos. Wellek \& werren (199:223) mitos bagian ritual yang di ucapkan, cerita yang diperagakan oleh ritual. Dalam masyarakat, ritual biasa diperagakan oleh tokoh pemuka agama, yang bertujuan untuk menghindari bahaya atau mendatangkan keselamatan. Mitos-mitos atau ritual kebanyakan dari kalangan masyarakat pedalaman yang masih kental dengan adat di lingkungannya.

Novel simple miracles doa dan arwah karya Ayu utami merupakan karya sastra yang banyak kaitannya dengan kehidupan masyarakat lokal yang masih kental dengan adat ataupun mitos-mitos setempat. Tujuan daripada penelitian ini ialah untuk menjelaskan dan menggungkapkan makna yang di maksud dalam novel, juga sebagai bentuk penggungkapan karya sastra terhadap realita kehidupan di dalam masyarakat lokal yang mana pengarang memilih topik untuk di jadikan konflik dalam karyanya, sekaligus karya sastra mempunyai peran penting untuk menyampaikan ke adaan sosial masyarakat.

Novel doa dan arwah menggambarkan keyakinan seseorang yang direpresentasikan melalui sikap tokoh yang tidak percaya kepada hal-hal ghaib dan mistis. Keyakinan semacam itu berhubungan dengan lingkup social dan interaksi social yang ada dalam hidupnya. Karena bagian dari keluarganya memiliki keyakinan kepada hal-hal ghaib dan mistis, tetapi bagi tokoh "aku" hal-hal seperti itu bukanlah hal yang bisa dipercayai.

Teori dan metode yang di gunakan adalah hemeneutika. Metode ini di gunakan untuk penelitian teks-teks yang sifatnya otoritatif (Fitria, 2016). Metode ini dianggap ilmu tafsir yang di gunakan untuk meneliti teks yang mengarah pada religi seperti kitab suci pada agama (Ratna,2015:46). Aristotele menyatakan bahwa hermeneutikadalah syarat terpenting bagi setiap ilmu pengetahuan yang mendasarkan keabsahannya pada interpretasi teks - teks. Istilah hermeneutika pada jaman sekarang (kontemporer) dapat dilihat dari dua sudut pandang yaitu, Hermeneutika sebagai seperangkat prinsip metodologis penafsiran dan hermeneutika sebagai penggalian filosofis dari sifat dan kondisi yang tidak bisa dihindari dari kegiatan pemahaman teks (Fitria, 2016).

Menindaklanjuti pernyataaan di atas bahwasannya mitos yang ada di dalam novel merupakan mitos kelahiran, kematian dan mitos setelah kematian.oleh karena itu pendekatan antropologi sangat 
relevan jika peneliti ingin meneliti terkait mitos di dalam novel simple miracles doa dan arwah karya Ayu utami. Sebagaimana antropologi merupakan ilmu yang berkaitan dengan manusia dalam masyarakat (Ratna, 2015:63).

Penelitian ini pernah di lakukan oleh (1) Risnawati, dalam tulisannya membahas terkait kepercayaan dalam budaya jawa dan bentuk ritual-ritul di adalam budaya jawa (Risnawati, 2017). (2) Mulia, pembahasan hampir sama dengan pernyataan peneliti yang pertama, akan tetapi peneliti ini mengarah pada realisme magis. Konflik yang di ambil kebudayaan masyarakat jawa yang masih ketal dengan kedekatannya terhadap makhluk halus, seperti dukun, paranormal dll (Mulia, 2016).

Menanggapi pernyataan di atas bahwasannya, ke dua peneliti tersebut masih mempunyai keterbatasan pembahasan di dalam tulisannya. Oleh karena itu peneliti ingin meneliti kembali dengan harapan menemukan hasil yang berbeda terkait penelitian mitos yang ada pada novel simple miracles doa dan arwah akrya ayu utami. Akan tetapi tidak menutup kemungkinan bahwasannya peneliti di atas sangat mmembantu peneliti mengenai pencarian atau penggalian informasi.
Kisah novel simple miraclesdoa dan arwah ini, tokoh "aku" yang mempunyai pemikiran kritis terkait ritual yang diketahui setelah paska kematian manusia. Tokoh "aku" menelusuri gejala-gejala sampai dengan pembahasan terkait do'a serta mencari tahu tujuan dari pada doa untuk manusia yang sudah mati ataupun masih hidup. Sehingga memunculkan kembali kepercayaan tokoh "aku" terkait gejala-gejala yang dianggapnya tahayul (mitos). Maka dari itu berdasasarkan problematika yang mendorong peneliti memilih novel Simple Miracles Doa dan Arwah sebagai objek penelitian, dan peneliti berfokus kepada representasi tokoh utama terhadap mitos yang ada pada novel karya Ayu utami tersebut. Maka peneliti ingin mengungkapkan mitos yang ada pada msyarakat sebagaimana pemaknaan dari sebuah karya sastra novel melalui tokoh utama dalam kisahnya.

\section{KAJIAN PUSTAKA}

Teori yang digunakan dalam penelitian ini adalah teori Hermeneuitika. hermeneutika merupakan teori tentang kaidah-kaidah yang menata sebuah eksegesis, dengan kata lain, sebuah interpretasi teks partikular atau kumpulan potensi tandatanda keberadaan yang dipandang sebagai sebuah teks. Hermeneutika adalah proses penguraian yang beranjak dari isi dan makna yang nampak ke arah makna 
terpendam dan tersembunyi. Hermenetik menurut pandangan kritik sastra ialah Sebuah metode untuk memahami teks yang diuraikan dan diperuntukkan bagi penelaahan teks karya sastra. Hermenetik cocok untuk membaca karya sastra karena dalam Kajian sastra, apa pun bentuknya, berkaitan dengan suatu aktivitas yakni interpretasi (penafsiran). Kegiatan apresiasi sastra dan kritik sastra, pada awal dan akhirnya, bersangkutpaut dengan karya sastra yang harus diinterpreatasi dan dimaknai. Karya sastra perlu di tafsirkan sebab disatu pihak karya sastra terdiri atas bahasa dipihak lain didalam bahasa sangat banyak makna yang tersembunyi atau dengan sengaja disembunyikan.

Teori hermeneutika sangat cocok digunakan dalam analisis ini dikarenakan sikap tokoh yang tercermin dalam novel Simple Miracle ini memiliki penafsiran yang tersembunyi dalam sikap tokoh dalam representasi kehidupan. Dengan penegasan pada beberapa sikap tokoh yang diceritakan mampu melihat atau berkomunikasi dengan mahluk ghaib merupakan sebuah hal yang perlu dikaji mengapa bisa terjadi seperti itu dan makna apa yang terkandung dalam cerita yang demikian.

\section{METODE}

Hermeneutika, merupakan studi ilmu yang di kenal membahas tentang representasi makna teks kedalam bahasa dan budaya (Risnawati, 2017). Dengan menggunakan metode teori hermeuntika maka akan menemukan gejala-gejala atau peristiwa, tanda, simbol, dan mitos yang ada di dalam sebuah karya sastra dengan perantaraan bahasa dan budaya. Jadi hermeneutika merupakan teori metode yang sinkron jika peneliti ingin meneliti representasi sikap tokoh utama dalam mitos novel simple miracles: doa dan arwah karya Ayu utami. Dengan begitu peneliti akan menemukan fenomena atau permaslahan yang ada pada tokoh "aku" di dalam novel tersebut. Hermeneutika tidak hanya mengkaji pemaknaan tanda atau simbol dalam bahasa atau budaya, akan tetapi lebih jauh mendalam, sehingga sampai menemukan sebuah tafsiran pada fenomena yang ada pada teks sebuah karya sastra (Ratna, 2015:46).

Adapun langkah-langkah untuk meneliti permasalahan yang ada pada novel ini yaitu pertama menentukan topik. Dalam tahap ini penulis sudah menentukan topik permasalahan yaitu representasi sikap tokoh dalam mitos novel simple miracles doa dan arwah karya Ayu utami. Yang ke dua peneliti melakukan pengumpulan data, pengumpulan data di sini peneliti mengumpulkan dialog tokoh 
Aku yang ada di dalam novel tersebuat. Tahap selanjutnya yaitu yang ke tiga, peneliti mengolah data-data yang sudah terkumpul kemudian di kaitkan dengan masalah yang ingin di analisis. Setelah peneliti melakukan pengolahan data kemudian peneliti melakukan analisis terkait permasalahan yang akan di teliti. Di tahap inilah kemudian peneliti menemukan bentuk reprentasi sikap tokoh Aku yang ada di dalam novel simple miracles doa dan arwah. Kemudian penarikan kesimpulan, agar penelitian ini sesui dengantujuan penelitian yang telah di tetapkan.

\section{HASIL DAN PEMBAHASAN}

Dalam novel simple miracles doa dan arwah, tuhan adalah kepercayaan tertinggi dalam kehidupannya, akan tetapi tokoh aku memiliki perbedaan pemikiran terhadap tuhan.

"Sekarang aku berpikir-pikir sendiri. Tidakkah suatu standar ganda jika ibuku skeptis terhadap hantu tetapi beriman tentang Tuhan? Dari kacamata seorang ateis, apa beda hantu dan Tuhan?" (Utami, 2014: 101)

Dalam pernyataan selanjutnya
sikap tokoh melakuakan penguatan
terhadap kepercayaanya dengan
membandingkan tuhan dengan hantu.

"Hantu tidak datang dengan paket nilainilai, Tuhan datang dengan paket nilainilai. Hantu tidak datang dengan etika dan ajaran. Kepercayaan pada hantu seru tapi tidak memawa kita kemana-mana. Kepercayaan pada Tuhan membawa kita ke suatu arah.” (Utami, 2014: 101)

Pernyataan selanjutnya, dimana tokoh aku mempunyai sikap kritis terkait hantu dan tuhan bahkan dalam novel terdapat pertanyaan yang mengaitkan tentang agama

“apa beda takhayul dengan agama? Seperti yang sudah kubilang, takhayul itu seperti jika kita menyelesaikan PR matematika dengan doa atau jampi-jampi. Kita boleh saja memulai PR dengan doa atau mantra. Tapi kita tidak mengerjakannya dengan komat-kamit atau ayat-ayat. Takhayul itu jika kita menyelesaikan persoalan yang bisa diukur dengan hal-hal yang tak dapat diukur." (Utami, 2014: 102)

Percakapan tersebut menggambarkan bahwa takhanyul itu hanya sebuah pikiran yang tak bisa di rasionalkan dalam kehidupan tokoh aku. Tokoh aku dengan sikap kritisnya bahwasannya menginginkan kebenaran yang bersifat materialis. Dalam percakapan selanjutnya.

"sedangkan agama... Yah, dalam sejarahnya agama memang sering 
menjengkelkan. Seperti gereja katolik yang idak mau mengakui Galilio Galilei. Tapi pelan-pelan mereka belajar mengaku dosa juga, meski malu-malu. Dengan segala kelemahan dan sok kuasanya, institusi agama juga mengerjakan banyak hal: memelihara seni dan filsafat, mempergulatkan moralitas, memelihara ikatan dan belarasa. Takhayul tidak mendorong orang mengerjakan hal itu". (Utami,2014: 102)

Diawal alenia percakapan di atas, tokoh aku melihat bahwasannya tidak ada konsisten dalam beragama, agama dan takhayul tidak ada keselarasan, dan tokoh aku menyadari bahwa dalam sejarah perjalanan agama sangatlah rumit dan banyak ketidakpastian dalam agama.

Akan tetapi dalam perjalannya tokoh menemukan jawaban, yang mulanya tidak mempercayai tuhan, kemudian tokoh mempercayai adanya tuhan sebagaimana harus di imani

"Begitulah aku hidup dalam suatu sistem makna yang kukenal, perpaduan dari sistem makna Katolik, Jawa, Indonesia, pengalaman keluarga, kesukaan pribadi, dan lainlain. Sistem itu membuat aku memaknai peristiwa-peristiwa hidupku. Aku melihat doa-doa yang terkabul dengan indah.”(Utami, 2014: 168)
Dalam pernyataan di atas terdapat nilai moral dan pembelajaran bahwasannya mempercayai bukan sekedar percaya akan tetapi harus ada keyakinan dalam diri manusia sehingga akan mendapatkan ke bahagiaan setelah manusia mempunyai akhlak yang baik.

\section{KESIMPULAN}

Informasi tentang masa depan ataupun dunia roh menggelisahkan dan akan membuat rentan manusia. Ada yang memburunya dan ada pula yang menutup diri terhadapnya. Manusia tidak hanya percaya terhadap tuhan, akan tetapi yakin akan keberadaan tuahan. Sehingga manusia tidak hanya percya terhadap tuhan akan tetapi percaya bahwasannya makhluk halus juga harus di percayai. Sikap tokoh ini mengingatkan kembali kepada pengajaran kepribadian yang baik, mulai dari sikap dan perilaku. Sehingga menciptakan karakter dan berakhlak baik.

Mendoakan orang yang sudahmeninggal merupakan salah satu wujud daripada kasih sayang manusia terhadap manusia lainnya. Mitos yang di hadirkan dalam novel simple miracles doa dan arwah karya Ayu utami ini, banyak mengajarkan nilai karakter terhadap manusia, dan juga mengingatkan bahwasannya hal yang di lakuan sebagian masyarakat yang masih menggunakan 
ritual seperti yang di kisahkan pada novel tersebut sangatlah baik, karena tujuan melakukan hal itupun untuk mendoakan dan sebagian dari wujud kasih sayang.

\section{DAFTAR PUSTAKA}

Fitria, R. (2016). MEMAHAMI

HERMENEUTIKA DALAM MENGKAJI TEKS. syi'ar, 33-42.

Mulia, S. W. (2016). REALISME MAGIS

DALAM NOVEL SIMPLE MIRACLES

DOA DAN ARWAH KARYA AYU

UTAMI . LAKON, 1-20.

Prof. Dr. Nyoman Kutha Ratna, S. (2015).

Teori, Metode dan Teknik Penelitian

Sastra. Yogyakarta: Pustaka Pelajar.

rene, w., \& austin, w. (2016). teori

kesusastraan. Jakarta: PT Gramedia

Pustaka Utama.

Risnawati. (2017). BENTUK MITOS

JAWA DALAM NOVEL SIMPLE

MIRACLE: DOA DAN ARWAH

KARYA AYU UTAMI SEBAGAI

PIRANTI PENDIDIKAN KARAKTER

(KAJIAN ANTROPOLOGI SASTRA).

SENASBASA, 341-351.

Utami, A. (2017). Simple miracles doa dan arwah. Jaakarta: KPG. 